\title{
Renal sphaerosporosis in cultured grouper Epinephelus malabaricus
}

\author{
K. Supamattaya ${ }^{1,2}$, Th. Fischer-Scherl' ${ }^{2}$, R. W. Hoffmann ${ }^{2,}$, S. Boonyaratpalin ${ }^{3}$ \\ ${ }^{1}$ Faculty of Natural Resources, Prince of Songkla University, Hatyai, Songkla 90112, Thailand \\ ${ }^{2}$ Institute of Zoology and Hydrobiology, University of Munich, Kaulbachstr. 37, D-8000 München 22, Federal Republic of \\ Germany \\ ${ }^{3}$ National Institute of Coastal Aquaculture, Department of Fisheries, Songkla 90000, Thailand
}

\begin{abstract}
In kidneys of diseased cage-cultured grouper Epinephelus malabaricus, a heavy infestation with myxosporean developing stages, belonging to a Sphaerospora spp., was proven using histological and electron-microscopical techniques. Kidney tubule lumens were heavily filled with mature spores and developing stages adhering to the brush border of the tubules. Renal corpuscles were also affected. No pathogenic bacteria or viruses were identified as causative agents of the disease. This is the first report of sphaerosporosis in brackish water fish cultured in south-east Asia.
\end{abstract}

\section{INTRODUCTION}

Members of the genus Sphaerospora are known to occur mostly in kidney tubules and urinary bladder, but they have also been described from gall bladder, skin and gills. Most Sphaerospora spp. do not affect the host organ, but some species can act as pathogen and provoke tissue damage, as has been documented in common carp Cyprinus carpio (Molnár 1980: Sphaerospora angulata Fujita, 1912, syn. S. renicola Dykova \& Lom, 1982) and in brown trout Salmo trutta (Fischer-Scherl et al. 1986a: Sphaerospora truttae). Hermanns \& Körting (1985) described Sphaerospora tincae Plehn, 1925 in the head kidney of tench Tinca tinca, while Hedrick et al. (1988) and Odening et al. (1988) reported on the coincidence of a Sphaerospora sp. with PKX organisms in the kidney of rainbow trout Salmo gairdneri.

Studies on infestation by this parasite have been concentrated in Europe, where economic losses in commercial freshwater fish species have occurred (Dykova \& Lom 1988). To date, 6 species of Sphaerospora are known from the urinary tract of marine or brackish water fish (Arthur \& Lom 1985). It is very probable that members of the genera Leptotheca, common in marine fishes, and which have similar spores, have to be regarded as synonyms of the genus Sphaerospora (Lom \& Noble 1984).

\footnotetext{
- Addressee for correspondence
}

So far disease outbreaks comparable to those of freshwater fishes have not been recorded in marine or brackish water fish infected with a Sphaerospora sp. Although the life cycle of Sphaerospora renicola is well understood (Molnár \& Kovaćs-Gayer 1986, Molnár 1988) the developmental cycle of other species remains unclear. It is possible that the parasites are transported to the kidney via the bloodstream passing through the glomerula. Heavily destroyed glomerula, with developing stages located in the Bowman's space, have been found in carp Cyprinus carpio (Molnár 1980) and in brown trout Salmo trutta (Fischer-Scherl et al. 1986a, b) with kidney sphaerosporosis.

Disease symptoms have occurred in cage-cultured grouper Epinephalus malabaricus on both coastlines of southern Thailand (Gulf of Thailand and Andaman Sea) and also in Malaysia for the past few years. In 1988 more intensive studies on the disease were undertaken and a heavy infestation of Sphaerospora sp. in kidneys was found. This is the first report of sphaerosporosis in brackish water fish cultured in south-east Asia.

\section{MATERIALS AND METHODS}

Grouper Epinephelus malabaricus, showing signs of disease, were taken from several cage-culture sites in Songkla and Satun provinces to the National Institute of Coastal Aquaculture (Thailand). Diseased fish with a 
weight range of 100 to $800 \mathrm{~g}$ in cage-cultured and of 15 to $20 \mathrm{~kg}$ in brood fish at fishery stations were examined. External parasites from the skin and gills, and any external clinical signs of disease were recorded. Bacterial examinations were performed from external lesions, liver and kidney of diseased fish into blood agar or tryptic soy agar $+1.5 \% \mathrm{NaCl}$ and incubated for 24 to $48 \mathrm{~h}$ at 25 and $35^{\circ} \mathrm{C}$, respectively. The possibility of viral infection was determined using parts of external lesions, liver and kidney tissue on fish cell
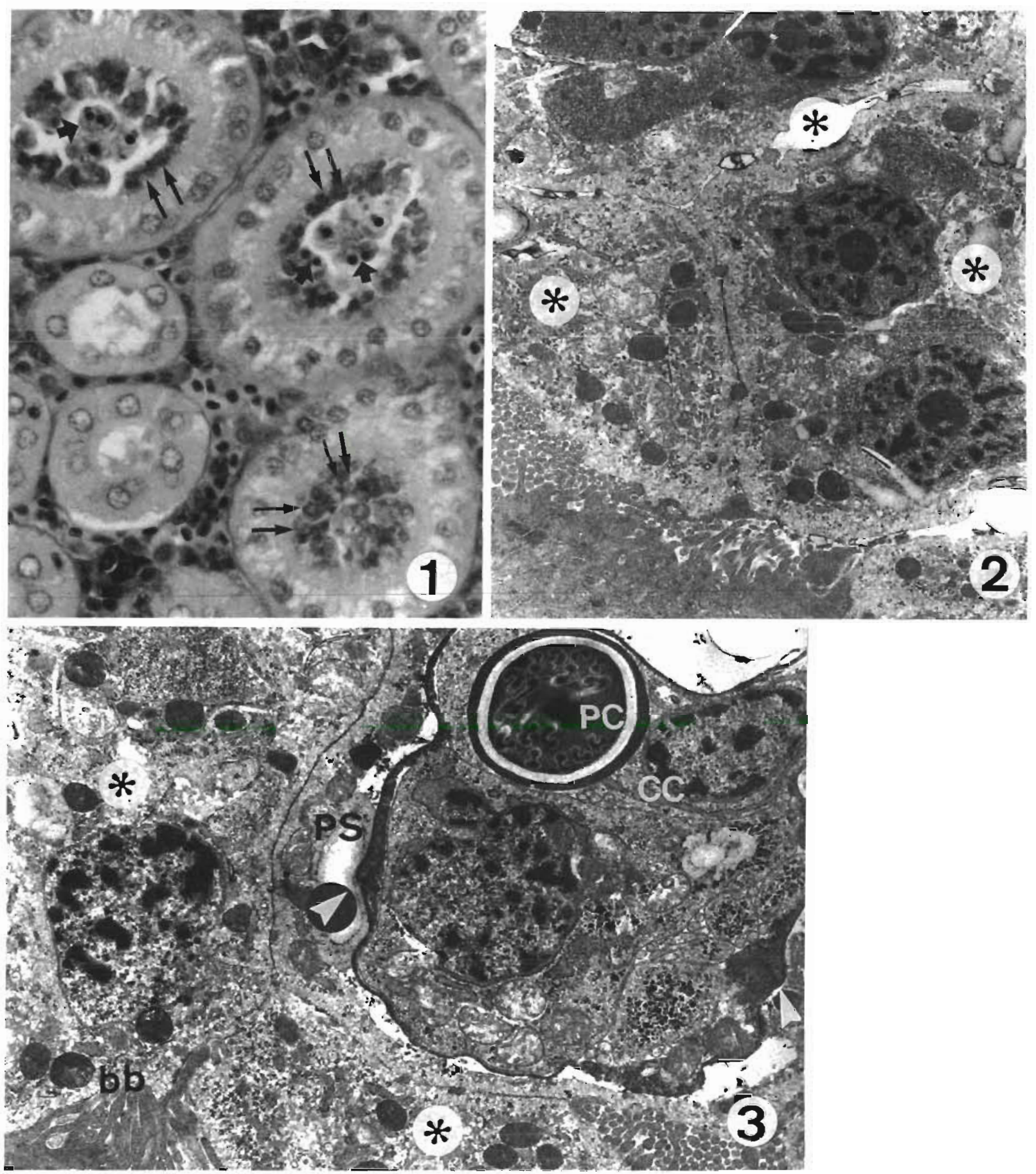

Figs. 1 to 3. Epinephelus malabaricus. Fig. 1. Kidney tubule lumens filled with Sphaerospora sp. Mature spores ( with 2 distinct spherical polar capsules are located in the middle of the lumen while developing stages line the brush border ( $\uparrow \uparrow)$. Giemsa's stain, $\times 590$. Fig. 2. Early pseudoplasmodia (*) adhering to the brush border of renal tubule, TEM, $\times 15800$. Fig. 3. Maturing spore of Sphaerospora sp. inside a pseudoplasmodium (PS). Arrows head indicates junction of flat shell valves. CC: Capsulogenic cells; PC: polar capsule; bb: brush border; *: early pseudoplasmodia. TEM。 $\times 13000$ 
lines from EPC, FHM and BF-2. The cell cultures were incubated at $25^{\circ} \mathrm{C}$ and examined on a daily basis for $14 \mathrm{~d}$ after inoculation in order to observe any cytopathic effects (CPE).

Tissues from skin, air bladder, liver, kidney, intestine, spleen, brain and heart were fixed in $10 \%$ buffered formalin and in $5 \%$ glutaraldehyde in $\mathrm{Na}$ cacodylate buffer ( $\mathrm{pH} 7.4)$. Specimens were then processed for light- and electron-microscopy.

\section{RESULTS AND DISCUSSION}

Diseased fish suffered from a loss of equilibrium and were floating or turning upside down; some fish had haemorrhages on the mouth and body surfaces. Internal organs showed no signs of disease, although haemorrhages in the swim bladder were observed in some fish and swollen swim bladders in others.

Some external parasites, such as Trichodina, Cryptocaryon sp. and monogenetic trematodes on gills, were recorded in low numbers in both diseased and healthy fish. No pathogenic bacteria were isolated from any internal organs or external lesions. No CPE were detected in cell cultures after $14 \mathrm{~d}$ of inoculation.

From histological sections of the kidneys of diseased groupers, spores and pseudoplasmodia of a Sphaerospora sp. were observed in renal tubules. The spores were identified by typical characteristics such as 2 spherical polar capsules being equal in size. Mature spores were mostly located in the centre of tubule lumens, while large amounts of pseudoplasmodia were attached to the peripheral brush border of the epithelium of renal tubules (Figs. 1, 2). In many tubules filled with masses of spores and developing stages, the tubular epithelium became necrotic and peritubular fibrosis was indicated. Electron-micrographs of proximal tubular epithelial cells revealed increased amounts of lysosomes and myelinic figures. Renal corpuscles harbouring parasitic stages exhibited highly distended capillary loops and Bowman's spaces, while others were necrotic and shrunken.

Ultrastructure of the parasite showed similarities to previously described members of the genus Sphaerospora (S renicola: Lom et al. 1982, Desser et al. 1983; S. molnari: Desser et al. 1983; S. truttae: Fischer-Scherl et al. 1986b; S. tincae and S. galinae: Lom et al. 1985). The polar filament formed ca 4 to 5 windings (Fig. 3) and 2 uninucleated sporoplasm cells were seen. In Bowman's space of the renal corpuscles early stages of pseudoplasmodia were detected.

The disease outbreak associated with this parasite usually occurs in cage-cultured grouper from May to August, when water quality is generally poor (e.g. fluctuating salinity and low dissolved oxygen). How- ever, it is interesting to note that the same clinical signs and parasites were also recorded in broodfish cultured in offshore sites, where the water quality was good.

In general, Sphaerospora spp. do not affect wild fish severely. This is in contrast to cultured fish, where heavy outbreaks have been reported. It cannot be excluded that some factors such as stress (overcrowding, poor water quality) in fish ponds increase the susceptibility of cultured fish to Sphaerospora infection. In addition, a higher population density of cultured fish favours reinfection with the parasite.

Heavy infestation with the Sphaerospora parasite may also render fish more susceptible to other fish pathogens such as bacteria, viruses and parasites. Regarding pathomorphology of kidney in the described case, we are of the opinion that the outbreak of the disease is related to the myxosporean infection. Assuming that this Sphaerospora species develops in the same way as $S$. renicola, other organs may also be involved and probably are affected.

Unfortunately, only fixed material was provided for this investigation. We considered spores isolated from material fixed in formalin not to be suitable for accurate measurements on spore parameters. Further studies are in progress to identify this Sphaerospora sp. from fresh material and to clarify whether it is identical with other Sphaerospora spp. reported from brackish water fish.

Acknowledgements. The authors thank the Fish Disease Laboratory, Department of Microbiology, Oregon State University, USA, for providing fish cell culture, Dr A. Cronin for review of the manuscript and Miss $C h$. Kühnhauser for excellent technical assistance.

\section{LITERATURE CITED}

Arthur, J. R., Lom, J. (1985). Sphaerospora araii n.sp. (Myxosporea: Sphaerosporidae) from kidney of a longnose skate (Raja rhina Jordan and Gilbert) from the Pacific Ocean off Canada. Can. J. Zool. 63: 2902-2906

Desser, S. S., Molnar, K., Horvath, I. (1983). An ultrastructural study of the myxosporeans, Sphaerospora angulata and Sphaerospora carassii in the common carp. (Cyprinus carpio L.) J. Protozool. 30: 415-422

Dykova, I., Lom, J. (1988). Review of pathogenic myxosporeans in intensive culture of carp (Cyprinus carpio) in Europe. Folia parasitol. (Praha) 35: 289-307

Fischer-Scherl, Th., El-Matbouli, M., Hoffmann, R. (1986a). A new Sphaerosporasp. in brown trout (Salmo trutta $m$. fario) in Germany. Bull. Eur. Ass. Fish Path. 6: 16-19

Fischer-Scherl, Th., El-Matbouli, M., Hoffmann, R. (1986b). Light- and electronmicroscopical studies on a new Sphaerospora sp. in kidney of brown trout (Salmo trutta $m$ fario). In: Fijan, W. (ed.) Proc. Int. Symposium Ichthyopathology in Aquaculture, Dubrovnik, Oct. 21-24. p. 29

Hedrick, R. P., Kent, M. L., Toth, R. J., Morrison, J. K. (1988). Fish infected with Sphaerospora spp. Thelohan (Myxosporea) from waters enzootic for proliferative kidney disease of salmonids. J. Protozool. 35: 12-18 
Hermanns, W., Körting, W. (1985). Sphaerospora tincae Plehn, 1925 in tench. Tinca tinca L. fry. J. Fish Dis. 8: 281-288

Lom, J., Dykova, I., Lhotakova, M. (1982). Fine structure of Sphaerospora renicola Dykova and Lom, 1982, a myxosporean from carp kidney, and comments on the origin of pansporoblasts. Protistologica 18: 489-502

Lom, J., Körting. W., Dykova, I. (1985). Light- and electronmicroscope redescription of Sphaerospora tincae Plehn 1985 and S. galinae Evlanov, 1981 (Myxosporea) from the tench, Tinca tinca. Protistologica 21:487-498

Lom, J., Noble, E. R. (1984). Revised classification of the class Myxosporea Bütschli, 1881 Folia parasitol. (Praha). 31: 193-209

Responsible Subject Editor: Professor W. Körting, Hannover, F.R. Germany
Molnár, K. (1980) Renal sphaerosporosis in the common carp Cyprinus carpio L. J. Fish Dis. 3: 11-19

Molnár, K. (1988). Further evidence that C blood protozoa are stages of Sphaerospora renicola Dykova and Lom, 1982. Bull. Eur. Ass. Fish Path. 8: 3-4

Molnár, K., Kovacs-Gayer, E. (1986). Experimental induction of Sphaerospora renicola (Myxosporea) infection in common carp (Cyprinus carpio) by transmission of SB-protozoans. J. appl. Ichthyol. 2: 86-94

Odening, K., Walter, G., Bockhardt, I. (1988). Koinzidentes Auftreten von PKX und Sphaerospora sp. (Myxosporidia) in Beständen von Salmo gairdneri (Osteichthyes). Angew. Parasitol. 29: 137-148

Manuscript first received: July 22, 1989

Revised version accepted. November 30, 1989 